\section{AB1034 THE URATE-LOWERING EFFECT OF FEBUXOSTAT 80 MG AND 40 MG (80 MG FILM-COATED TABLETS SPLIT IN HALF) IN GOUT PATIENTS IN DAILY CLINICAL PRACTICE}

M. Flendrie ${ }^{1}$, B. van den Bemt ${ }^{2}$, V. Huiskes ${ }^{2}$, M. Hoefnagels ${ }^{1}$, F. van den Hoogen ${ }^{1}$. ${ }^{1}$ Rheumatology; ${ }^{2}$ Pharmacy, Sint Maartenskliniek, Nijmegen, Netherlands

Background: In Europe, the urate-lowering drug febuxostat for gout is registered in two strenghts, $80 \mathrm{mg}$ and $120 \mathrm{mg}$, but not $40 \mathrm{mg}$. Starting $40 \mathrm{mg}$ can sometimes be considered desirable, for instance for safety reasons. Splitting an $80 \mathrm{mg}$ film-coated tablet in half is an option, but is off-label and might violate coating function and influence effectiveness and safety.

Objectives: To investigate the urate-lowering effect and safety of starting febuxostat at $40 \mathrm{mg}$ once daily (80 mg film-coated tablet split in half) in gout patients compared to $80 \mathrm{mg}$ once daily.

Methods: Single-centre retrospective study on all gout patients starting febuxostat $80 \mathrm{mg}$ or $40 \mathrm{mg}$ (80 mg film-coated tablets split in half). Patients characteristics were collected, as well as starting dose and starting date of febuxostat, followup time, adverse events (AEs), stop date and reason, serum urate (sU) and creatinin (sCreat) over time and relevant comorbidity.

Patient characteristics were compared by Chi-square or T-test. Mean sU, percentual change from baseline and percentage of patients reaching targets $(\mathrm{sU}$ $<0.36$ or $0.30 \mathrm{mmol} / \mathrm{L}$ ) were tested using the appropriate t-test.

Results: 36 gout patients started febuxostat between April 1st 2012 and July 1st 2017. Twenty-three started on $80 \mathrm{mg}$ and 13 on $40 \mathrm{mg}$ once daily. Patient characteristics are shown in table 1. Table 2 shows mean $\mathrm{sU}$ at baseline and after start, percentage change in $\mathrm{s} U$ and percentage of patients reaching targets.

Median follow-up time was 1.6 years (range 0-6.7); 1.4 y (0-6.7) resp. $1.9(0.4-$ $5.5)$ for $80 \mathrm{mg}$ resp. $40 \mathrm{mg}$ group. Figure 3 shows mean $\mathrm{sU}$ per group in the first year.

5 of $36(14 \%)$ stopped during follow-up, all within 8 weeks after start and all because of AEs: diarrhoea ( $n=2,40 \mathrm{mg}$ and $80 \mathrm{mg})$, coronary syndrome $(n=1$, $80 \mathrm{mg}$ ), erectile dysfunction $(n=1,40 \mathrm{mg})$ and gout attacks $(n=1,40 \mathrm{mg})$. Other possible related AEs were dry mouth $(n=1,80 \mathrm{mg})$, elevated liver enzymes $(n=1$, $40 \mathrm{mg}$ ) and flushing ( $\mathrm{n}=1,40 \mathrm{mg})$

Abstract AB1034 - Table 1. Patient characteristics

\begin{tabular}{|c|c|c|c|c|}
\hline & $\begin{array}{l}\text { Total group, } \\
\mathrm{n}=36\end{array}$ & $\begin{array}{c}80 \mathrm{mg} \text { group, } \\
\mathrm{n}=23\end{array}$ & $\begin{array}{c}40 \mathrm{mg} \text { group, } \\
\mathrm{n}=13\end{array}$ & $\begin{array}{c}\mathrm{p}- \\
\text { value }\end{array}$ \\
\hline Age, y, median (range) & $60(33-90)$ & $60(34-90)$ & $64(33-87)$ & ns \\
\hline male gender, $\mathrm{n}(\%)$ & $29(81 \%)$ & $21(91 \%)$ & $8(62 \%)$ & $<0.05$ \\
\hline $\begin{array}{l}\text { time since diagnosis, } y \text {, median } \\
\text { (range) }\end{array}$ & $\begin{array}{c}1.7(-0.1- \\
13.0)\end{array}$ & $\begin{array}{l}0.8(-0.1- \\
12.3)\end{array}$ & $\begin{array}{c}2.9(0.9- \\
13.0)\end{array}$ & ns \\
\hline crystal prove, $n(\%)$ & $22(61 \%)$ & $15(65 \%)$ & $7(54 \%)$ & ns \\
\hline tophi*, $n(\%)$ & 15 (44\%) & $8(23 \%)$ & $7(54 \%)$ & ns \\
\hline $\begin{array}{l}\text { renal impairment (GFR 30-59 ml/min/ } \\
1.73 \mathrm{~m} 2), \mathrm{n}(\%)^{\$}\end{array}$ & $16(44 \%)$ & $7(30 \%)$ & $9(69 \%)$ & $<0.05$ \\
\hline other relevant comorbidity ${ }^{\#}, \mathrm{n}(\%)$ & $30(81 \%)$ & $19(83 \%)$ & $11(85 \%)$ & ns \\
\hline
\end{tabular}

*tophi information missing in 2. \$Lowest GFR was $30 \mathrm{ml} / \mathrm{min} / 1.73 \mathrm{~m} 2$. \#DM, obesitas,

hypertension, hyperlipidemia, cardiovascular disease

Abstract AB1034 - Table 2. Febuxostat effect on sU within 12 weeks

\begin{tabular}{|c|c|c|c|c|}
\hline & $\begin{array}{c}\text { Total group, } \\
\mathrm{n}=36\end{array}$ & $\begin{array}{c}80 \text { mg starting } \\
\text { dose, } n=23\end{array}$ & $\begin{array}{c}40 \mathrm{mg} \text { starting } \\
\text { dose, } \mathrm{n}=13\end{array}$ & $\begin{array}{c}\mathrm{p}- \\
\text { value }\end{array}$ \\
\hline $\mathrm{sU}$ at start, mean (SD) & $0.55(0.11)$ & $0.53(0.10)$ & $0.59(0.10)$ & ns \\
\hline $\begin{array}{l}\text { sU within } 12 \text { weeks*, } \\
\text { mean (SD) }\end{array}$ & $0.35(0.12)^{\star \star}$ & $0.31(0.10)^{\star *}$ & $0.39(0.10)^{\star \star}$ & $<0.01$ \\
\hline $\begin{array}{l}\% \text { on target }<0.36 \mathrm{mmol} / \\
\mathrm{L}\end{array}$ & $68 \%$ & $76 \%$ & $57 \%$ & ns \\
\hline $\begin{array}{l}\% \text { on target }<0.30 \mathrm{mmol} / \\
\mathrm{L}\end{array}$ & $36 \%$ & $50 \%$ & $8 \%$ & $<0.01$ \\
\hline $\begin{array}{l}\% \text { change in sU, mean } \\
\text { (SD) }\end{array}$ & $35(18)$ & $40(18)$ & $32(17)$ & ns \\
\hline
\end{tabular}

*available in resp. 33, 21 and 12. ** -value within groups $<0.001$ compared to baseline

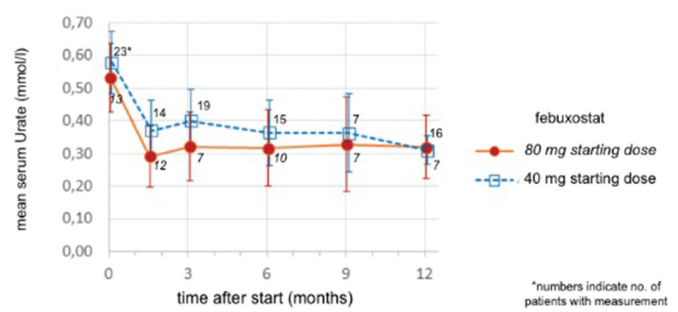

Abstract AB1034 - Figure 1. mean serum Urate over time after start of febuxostat
Conclusions: Both daily dosages febuxostat of 80 and $40 \mathrm{mg}(80 \mathrm{mg}$ film-coated tablets split in half) result in significant decline in sU levels within 12 weeks. A starting dose of $80 \mathrm{mg}$ febuxostat appears more effective in reducing sU levels. Selection bias may be a problem.

Disclosure of Interest: None declared

DOI: 10.1136/annrheumdis-2018-eular.5321

\section{AB1035 ULTRA-LOW DOSE ANTI-INTERLEUKIN1 IN CHRONIC GOUT: A SAFE AND SUCCESSFUL COMBINATION THERAPY WITH LOW DOSE COLCHICINE AND URATE LOWERING AGENTS}

M. Capassoni, F. Galluccio, M. Matucci Cerinic. AOUC Careggi, Reumatologia, Firenze, Italy

Background: Gout is the most common inflammatory arthritis in humans; is caused by deposition of monosodium urate (MSU) crystals within and around joints. Left untreated, a more chronic course may develop, characterised by persistent inflammation and visible MSU deposits (tophi), bone erosion, irreversible joint damage, and significant disability..$^{1}$ Management is based on two strategies: treating pain and inflammation with NSAIDs, steroids and colchicine and preventing flares and urate deposition with urate-lowering therapy $\left(.{ }^{2}\right.$ For many patients, standard treatments are ineffective or contraindicated, mainly due to comorbidities $\left(.^{3}\right.$ The main mechanism of crystal-induced inflammation is interleukin $1 \beta$ (IL$1 \beta)\left({ }^{4}\right.$ which strengthens the relevance of targeting IL-1 $\beta$ in patients with crystalinduced arthritis. Selective blockade of IL-1 $\beta$ has shown to drastically reduce pain, inflammation and risk of flares. Three biologic therapies inhibits IL-1 $\beta$ and have been studied for difficult to treat acute gouty arthritis flares: anakinra, rilonacept and canakinumab..$^{5-6}$

Objectives: Evaluate the efficacy of low dose anti-IL1 inhibitors administer by sublingual route in gout arthritis with remitting course that cannot be completely controlled with standard therapy regimens

Methods: Inclusion criteria was diagnosis of chronic gouty arthritis with remitting course (acute flares in patients with chronic gout and no inter-critical period), high CRP levels and need of chronic assumptions of NSAIDs or steroids, with flare at suspension. 20 patients fulfilled the criteria (exclusion criteria: intolerance to the study drug, poor compliance to therapies or diet, hyperuricemia, end stage renal disease) The study consist of two consecutive parts. An observational part were patients are treated for 6 months with $0.5-1 \mathrm{mg} /$ daily of colchicine and $300 \mathrm{mg}$ daily of allopurinol. They performed visits at baseline, 3 and 6 months and we collected data about blood tests, VAS score, number of flares, compliance to therapy and adverse events. An experimental part were we added GUNA anti-IL1 (an infinitesimal dilution of anakinra that has has a concentration of $10 \mathrm{fg} / \mathrm{mL}$ ) 20 drops administered SL. Again patients performed visits at baseline (which coincides with the last visit of the observational phase), 3 and 6 months and we collected the same kind of data.

Results: At 6 months after introduction of GUNA anti-IL1 all patients, except 1, experienced no flares of disease, levels of CRP became negative and VAS pain scale was significantly reduce (CRP level $p<0.0001$; VAS $p<0.0001$ ). NSAIDs and steroid consumption was significantly reduced. No adverse events happened Conclusions: Ultra-low dose of anti-IL1 agents added to standard therapy is an effective and safe way to achieve disease remission

\section{REFERENCES:}

[1] Richette P Gout. Lancet 2009, 375:318-328.

[2] Zhang W EULAR evidence based recommendations for gout. Part II: management. Ann Rheum Dis 2006, 65:1312-1324.

[3] N, Schlesinger Difficult-to-treat gouty arthritis: a disease warranting better management. Drugs. 2011 Jul 30;71(11):1413-39.

[4] Martinon F Gout-associated uric acid crystals activate the NALP3 inflammasome. Nature 2006, 440:237-241.

[5] So A A pilot study of IL-1 inhibition by anakinra in acute gout. Arthritis Res Ther 2007, 9:R28.

[6] Chen K Anakinra's efficacy is variable in refractory gout: report of ten cases. Semin Arthritis Rheum 2010, 40:210-214.

Disclosure of Interest: None declared DOI: 10.1136/annrheumdis-2018-eular.7590 